\title{
Pericarp polypeptides and SRAP markers associated with fruit quality traits in an interspecific tomato backcross
}

\author{
J.H. Pereira da Costa ${ }^{1,2}$, G.R. Rodríguez ${ }^{1,2}$, G.R. Pratta ${ }^{1,2}$, L.A. Picardi ${ }^{2,3}$ \\ and R. Zorzoli ${ }^{2,3}$ \\ ${ }^{1}$ Consejo Nacional de Investigaciones Científicas y Técnicas, \\ Buenos Aires, Argentina \\ ${ }^{2}$ Cátedra de Genética, Facultad de Ciencias Agrarias, \\ Universidad Nacional de Rosario, Zavalla, Santa Fe, Argentina \\ ${ }^{3}$ Consejo de Investigaciones de la Universidad Nacional de Rosario, \\ Rosario, Santa Fe, Argentina
}

Corresponding author: J.H. Pereira da Costa

E-mail: jpereira@unr.edu.ar

Genet. Mol. Res. 13 (2): 2539-2547 (2014)

Received May 24, 2013

Accepted September 18, 2013

Published January 24, 2014

DOI http://dx.doi.org/10.4238/2014.January.24.10

\begin{abstract}
The aim of this study was to detect polypeptides and genomic regions associated with fruit quality traits in a backcross generation using as parent the Argentinean cultivated tomato Caimanta of Solanum lycopersicum and the wild accession LA722 of S. pimpinellifolium. We tested two types of molecular marker: polypeptide profile (at two ripening stages, mature green and red ripe) and SRAP (sequence-related amplified polymorphism). A polypeptide of $45 \mathrm{kDa}$
\end{abstract}


present in the wild parents at the mature green stage was associated with larger fruit and long shelf life. Some amplification fragments from SRAP markers were associated with more than one quality trait such as fruit color, firmness, titratable acidity, and fruit soluble solids content. This study demonstrated for the first time the usefulness of the polypeptide profiles of pericarp and SRAP markers in finding associations with quality fruit traits in a tomato backcross generation.

Key words: Fruit shelf life; SDS-PAGE; Solanum lycopersicum; Solanum pimpinellifolium

\section{INTRODUCTION}

The cultivated tomato (Solanum lycopersicum) is an economically important Solanaceae in the world, where fruit quality plays an important role in the choice of cultivars by producers and even more by consumers. It is well known that domestication and subsequent allele fixation due to type-autogamous reproduction have led to a reduction in variability among cultivated genotypes (Rick, 1988). Several molecular studies have shown that much of the genetic variability is still present in wild genotypes (Miller and Tanksley, 1990; Labate et al., 2011). Several authors (Zorzoli et al., 2000; Pereira da Costa et al., 2009; Rodríguez et al., 2010) found that genotypes of wild species and their crosses with the cultivated tomato had longer shelf life when compared to commercial cultivars. Moreover, they also had better fruit quality such as color, texture, and sugar content.

The application of molecular markers allows the location of genes of interest in the genome, thus avoiding the time and the space needed in breeding programs. Among the DNA molecular markers, the SRAP (sequence related amplified polymorphism) are PCR-based markers that preferentially amplify expressed genomic regions according to the designed primer sequences ( $\mathrm{Li}$ and Quiros, 2001). They have been used for genotyping different species such as Cucurbita pepo (Ferriol et al., 2003, 2004), Spanish traditional cultivars of tomato (Ruiz et al., 2005) and Cynara cardunculus (Cravero et al., 2007), but they have not been used to analyze tomato segregating generations.

Although relatively few differences exist between the wild and domesticated tomato species at the genome sequence level (Tomato Genome Consortium, 2012), these differences probably affect protein functions (Michael and Alba, 2012). Therefore, polypeptide profiles would be appropriate molecular markers to characterize genotypes in several species (Del Duca et al., 2000; Castro et al., 2006). The first phase of cell division that occurs in tomato fruit development is followed by cell expansion until reaching the final stage in which the fruit matures. At this stage of maturity the accumulation of carotenoid pigments and fruit softening allow the distinction between different stages: mature green MG (fully expanded unripe fruit with mature seed), breaker (BR; first visible carotenoid accumulation), and red ripe (Giovannoni, 2004). The concentrations of polypeptides in the fruit tissues are finely regulated by biochemical processes that occur during ripening, which are related to genetic and environmental cues. Several reports have demonstrated the utility of total pericarp protein profiles as molecular markers in $\mathrm{F}_{2}$ and RIL populations of tomato (Rodríguez et al., 2008, 2011; Gallo et al., 2010). To date, neither SRAP nor polypeptide profiles have been used as molecular markers in backcross populations of tomato to detect QTLs (quantitative trait loci) involved in fruit quality traits.

The aim of this work was to detect polypeptides and genomic regions associated with 
fruit quality traits. To accomplish this goal, we tested two types of molecular marker: polypeptide profile and SRAP in a backcross generation using as parents the Argentinean cultivated tomato Caimanta of S. lycopersicum and the wild accession LA722 of S. pimpinellifolium.

\section{MATERIAL AND METHODS}

\section{Plant material}

The Argentinean cultivar Caimanta of S. lycopersicum (CAI) was used as recurrent parent. Caimanta has a determinate growth habit, compact plants, flat fruit (diameter greater than height), with large fruit $(98.5 \pm 9.9 \mathrm{~g}$ ) and short shelf life ( $9.7 \pm 0.9$ days). The donor parent was the LA722 accession of S. pimpinellifolium with indeterminate growth habit, round, and small fruits $(0.9 \pm 0.1 \mathrm{~g})$ and long shelf life (18.7 \pm 0.4 days) (Rodríguez et al., 2006). The $\mathrm{F}_{1}$ generation was obtained by hand crossing following the technique described by Rick (1973) using the Caimanta cultivar as the female parent. The backcross 1 generation $\left(\mathrm{BC}_{1}\right)$ was obtained using the cultivated genotype as female parent. Ten seeds from each parent and $\mathrm{F}_{1}$ generation and 80 seeds of $\mathrm{BC}_{1}$ were germinated (Table 1). The seedlings were transplanted in a greenhouse in a completely randomized design. The distance between plants was $35 \mathrm{~cm}$ and row spacing was $1 \mathrm{~m}$.

\begin{tabular}{|c|c|c|}
\hline Genotypes & No. of plants & No. of fruits \\
\hline CAI of S. lycopersicum & 5 & 27 \\
\hline LA722 of S. pimpinellifolium & 10 & 132 \\
\hline $\mathrm{F}_{1}$ generation & 10 & 110 \\
\hline $\mathrm{BC}_{1}$ generation & 80 & 1240 \\
\hline Total & 115 & 1509 \\
\hline
\end{tabular}

\section{Phenotypic analysis}

Ten fruits per plant at breaker stage were harvested and the following fruit traits were evaluated: weight $(\mathrm{W}, \mathrm{g})$, diameter $(\mathrm{D}, \mathrm{cm})$, height $(\mathrm{H}, \mathrm{cm})$, shape $(\mathrm{Sh}$, height/diameter ratio), and shelf life (SL) as days from harvest to the beginning of fruit softening, following the methods described by Garg et al. (2008) and Pereira da Costa et al. (2009). In fruits harvested at red ripe stage, the following traits were evaluated: soluble solids content (SS, ${ }^{\circ}$ Brix) measured with a manual refractometer, $\mathrm{pH}$ and titratable acidity of the homogenized juice. The fruit firmness (F) was measured on the equatorial plane, in two opposite fruit areas with a durometer type Shore A (Durofel DFT100) with a tip of $0.10 \mathrm{~cm}^{2}$. The fruit color was evaluated by the darkness (L) and the ratio $\mathrm{a} / \mathrm{b}$. The parameters $\mathrm{L}$, $\mathrm{a}$ and $\mathrm{b}$ were determined with a Minolta ${ }^{\circledR} \mathrm{Chromameter}$ CR 400. The firmness and fruit color were determined in at least five fruits per plant.

\section{Molecular analysis}

\section{Pericarp total polypeptide profiles}

Pericarp total protein profiles were determined for fruits harvested at the mature green 
$(\mathrm{MG})$ and red ripe (RR) stages. Three independent samples (one fruit of three different plants) for parental genotypes and $\mathrm{F}_{1}$ and one sample per $\mathrm{BC}_{1}$ plant were harvested at each ripening stage and proteins were extracted from pericarp and separated by SDS-PAGE according to Rodríguez et al. (2008). Equal amounts of polypeptides $(20 \mu \mathrm{g})$ in each well were run for 1.5 $\mathrm{h}$ at $35 \mathrm{~mA}$ constant current. The gels were stained overnight with $0.1 \%$ Coomassie brilliant blue R-250 solution. The gels were then destained with boiling water, scanned and analyzed using the GelPro Analyzer 3.0 software.

\section{SRAP markers}

Young leaves were removed from the parents, $\mathrm{F}_{1}$ and each plant $\mathrm{BC}_{1}$, which were kept in a $-80^{\circ} \mathrm{C}$ freezer until DNA extraction, were done with a commercial kit (Wizard ${ }^{\circledR}$ Genomic DNA Purification Kit from Promega, USA). PCR amplifications were done in duplicate for the parental and the $\mathrm{F}_{1}$ genotypes.

Four primer combinations (Table 2) were used to characterize the parental genotypes, the $\mathrm{F}_{1}$ and $\mathrm{BC}_{1}$ generation. For PCR, the protocol proposed by Li and Quiros (2001) was used. The amplification fragments were separated by denaturing polyacrylamide gels $(5 \% \mathrm{w} / \mathrm{v})$ at room temperature and detected with a commercial silver staining kit (Silver Sequence ${ }^{\mathrm{TM}}$ Staining Reagents, Promega). Electrophoresis was carried out at $50 \mathrm{~W}$ constant current for $3 \mathrm{~h}$. The gels were analyzed with the GelPro Analyzer 3.0 software and the presence and absence of bands were scored as 1 and 0 , respectively.

Table 2. SRAP primer combinations (sequence related amplified polymorphism), forward and reverse primer
sequences.
\begin{tabular}{lll}
\hline Primer combinations & Primer forward & Primer reverse \\
\hline 1- Me1-EM2 & Me1: 5'-TGAGTCCAAACCGGATA-3' & EM2: 5'-GACTGCGTACGAATTTGC-3' \\
2- Me2-EM1 & Me2: 5'-TGAGTCCAAACCGGAGC-3' & EM1: 5'-GACTGCGTACGAATTAAT-3' \\
3- Me2-Ga34 & Me2: 5'-TGAGTCCAAACCGGAGC-3' & Ga34: 5'-CCAAATGGAACAAAATGATG-3' \\
4- Me8-Sa14 & Me8: 5'-TGAGTCCTTTCCGGTGC-3' & Sa14: 5'-TTACCTTGGTCATACAACATT-3' \\
\hline
\end{tabular}

\section{Statistical analysis}

The normal distribution of the traits in all generations was verified by the ShapiroWilk test (Shapiro and Wilk, 1965). The Student $t$-test (Snedecor, 1964) was used to compare means between parents and the $\mathrm{F}_{1}$. All statistical analyses were carried out with the InfoStat software Version 1.0 (Di Renzo et al., 2001).

Since the polypeptides and SRAP are both dominant markers, only the bands with Mendelian behavior in parents (presence in LA722 and absence in CAI) were taken into account to test the expected segregation in the $\mathrm{BC}_{1}(1: 1$, presence:absence). A chi-square test was used to test this segregation (Snedecor, 1964). The association analysis between molecular markers and quantitative traits was carried out by single point analysis (Tanksley, 1993). One-way ANOVA was performed, in which marker-genotype groups were used as a classificatory variable.

\section{RESULTS AND DISCUSSION}

Parental genotypes showed significant difference for most of the traits evaluated, ex- 
cept $\mathrm{pH}$ and fruit soluble solids content. In spite of this, a significant phenotypic variation was observed in the $\mathrm{BC}_{1}$ generation for these two traits (Table 3), which could indicate a broadening of genetic variance. A locus recombinant process could have been responsible for new gene combinations that extended the phenotype variation. As Rodríguez et al. (2006) postulated, recombination occurred during the process of obtaining RILs (from the same interspecific cross) since some RILs showed lower or higher phenotypic values than the parents for several fruit quality traits.

\begin{tabular}{|c|c|c|c|c|c|c|c|}
\hline \multirow[t]{2}{*}{ Phenotypic Traits } & \multirow{2}{*}{$\frac{\text { CAI }}{\text { Means } \pm \text { SE }}$} & \multirow{2}{*}{$\frac{\text { LA722 }}{\text { Means } \pm \text { SE }}$} & \multirow{2}{*}{$\frac{\mathrm{F}_{1}}{\text { Means } \pm \mathrm{SE}}$} & \multicolumn{4}{|c|}{$\mathrm{BC}_{1}$} \\
\hline & & & & Means \pm SE & Min. & Max. & $\mathrm{N}$ \\
\hline Diameter $(\mathrm{cm})$ & $6.46 \pm 0.28^{\mathrm{c}}$ & $1.22 \pm 0.03^{\mathrm{a}}$ & $2.17 \pm 0.03^{b}$ & $3.50 \pm 0.07$ & 1.35 & 4.66 & 74 \\
\hline Height $(\mathrm{cm})$ & $3.99 \pm 0.14^{\mathrm{c}}$ & $1.13 \pm 0.02^{\mathrm{a}}$ & $2.02 \pm 0.03^{b}$ & $2.97 \pm 0.05$ & 1.27 & 3.90 & 74 \\
\hline Shape & $0.65 \pm 0.03^{\mathrm{a}}$ & $0.95 \pm 0.03^{\mathrm{b}}$ & $0.93 \pm 0.01^{\mathrm{b}}$ & $0.86 \pm 0.01$ & 0.63 & 1.02 & 74 \\
\hline Weight (g) & $97.84 \pm 11.1^{\mathrm{c}}$ & $1.17 \pm 0.08^{\mathrm{a}}$ & $6.21 \pm 0.20^{\mathrm{b}}$ & $23.63 \pm 1.14$ & 1.39 & 42.94 & 74 \\
\hline SL (days) & $7.96 \pm 0.63^{\mathrm{a}}$ & $15.26 \pm 0.60^{\mathrm{b}}$ & $16.39 \pm 0.37^{b}$ & $13.53 \pm 0.49$ & 6.00 & 28.00 & 74 \\
\hline Firmness & $35.88 \pm 3.52^{\mathrm{a}}$ & $65.61 \pm 1.40^{c}$ & $49.30 \pm 1.97^{b}$ & $49.71 \pm 1.15$ & 27.60 & 76.50 & 51 \\
\hline Darkness (L) & $41.10 \pm 1.92^{\mathrm{c}}$ & $38.52 \pm 0.21^{\mathrm{b}}$ & $36.84 \pm 0.32^{\mathrm{a}}$ & $41.04 \pm 0.27$ & 37.67 & 45.63 & 51 \\
\hline $\mathrm{a} / \mathrm{b}$ & $0.94 \pm 0.04^{\mathrm{a}}$ & $1.42 \pm 0.02^{b}$ & $1.34 \pm 0.03^{b}$ & $1.02 \pm 0.02$ & 0.80 & 1.27 & 51 \\
\hline Soluble solids content $\left({ }^{\circ} \mathrm{Brix}\right)$ & $7.52 \pm 0.03^{\mathrm{a}}$ & $7.25 \pm 0.35^{\mathrm{a}}$ & $8.73 \pm 0.08^{b}$ & $6.27 \pm 0.12$ & 4.83 & 8.80 & 53 \\
\hline $\mathrm{pH}$ & $4.79 \pm 0.03^{\mathrm{a}}$ & $4.83 \pm 0.06^{\mathrm{a}}$ & $4.76 \pm 0.04^{\mathrm{a}}$ & $4.68 \pm 0.03$ & 4.19 & 5.16 & 49 \\
\hline Titratable acidity $(\mathrm{g})$ & $0.26 \pm 0.01^{\mathrm{a}}$ & $0.91 \pm 0.03^{\mathrm{c}}$ & $0.43 \pm 0.01^{\mathrm{b}}$ & $0.31 \pm 0.01$ & 0.11 & 0.59 & 51 \\
\hline
\end{tabular}

Different letters indicate significant differences at $5 \% \mathrm{~N}=$ number of plants evaluated.

Pericarp polypeptide profiles detected 27 bands at MG and 28 at RR stage in the parental genotypes. The level of polymorphism between CAI and LA722 at MG and RR stage was 70 and $64 \%$, respectively. Similar numbers of polypeptides and polymorphism percentage were found between parentals at both ripening stages. Twenty-seven bands and $33 \%$ of polymorphism were observed at the MG stage when CAI and $\mathrm{F}_{1}$ were compared. At the same ripening stage, 26 bands were detected when $\mathrm{F}_{1}$ and LA722 were compared and $50 \%$ the polymorphism was found. At the red ripe stage, $15 \%$ of polymorphism was observed when CAI and $F_{1}$ were compared for a total number of 20 bands. However, when LA722 and $F_{1}$ were compared, the polymorphism percentage was higher (54\%) with a total of 28 bands. Despite the similar polymorphism found between the parents, the hybrid had a different polypeptide profile. The appearance of de novo bands explains this result. De novo bands seem to be a frequent phenomenon when genotypes that have evolutionary divergences are studied. Rodríguez et al. (2011) found similar results when they compared the fruit polypeptide profiles in a cross between Caimanta and an accession of S. lycopersicum var. cerasiforme. De novo polypeptides could be the result of interactions of genetic contributions from the two parents or perhaps some transcriptional and/or posttranslational mechanisms would occur in the hybrid genetic background. The presence of stage-specific polypeptides was also observed by Rodríguez et al. (2011) and Gallo et al. (2010). In fact, the polypeptide profiles of tomato fruit pericarp at mature green and red ripe stages were capable of identifying these two ripening stages when 18 RILs were studied by Gallo et al. (2010).

Distortion in the segregation was observed because several bands did not have a 1:1 segregation in the $\mathrm{BC}_{1}$. Bands with skewed segregation were not taken into account for the association analysis, and de novo bands were not considered for subsequent analysis. At the MG 
stage, three polypeptides $(54,45$ and $38 \mathrm{kDa})$ showed Mendelian inheritance. The polypeptide of $45 \mathrm{kDa}$ detected at the MG stage (Figure 1-A) is particularly important since it is involved in giving the best ideotype of tomato for breeding programs (larger fruit with long shelf life) (Table 4). Moreover, none of these traits showed significant phenotypic correlations with other undesirable traits, except fruit shape, which was negatively correlated with fruit weight (data not shown). If these correlations are maintained in the same sense during the following generations, we may consider this polypeptide as a putative marker for these phenotypic traits in a future breeding program. At the red stage, only the $66-\mathrm{kDa}$ polypeptide was associated with $\mathrm{pH}(\mathrm{P}<0.05)$ (Table 4, Figure 1-B). In both cases $(54 \mathrm{kDa}$ at $\mathrm{MG}$ and $66 \mathrm{kDa}$ at $\mathrm{RR})$, it was observed that the polypeptide from wild parent decreased the mean value of $\mathrm{pH}$, explaining 11 and $12 \%$ of phenotypic variance, respectively. These polypeptides could be other putative molecular markers.
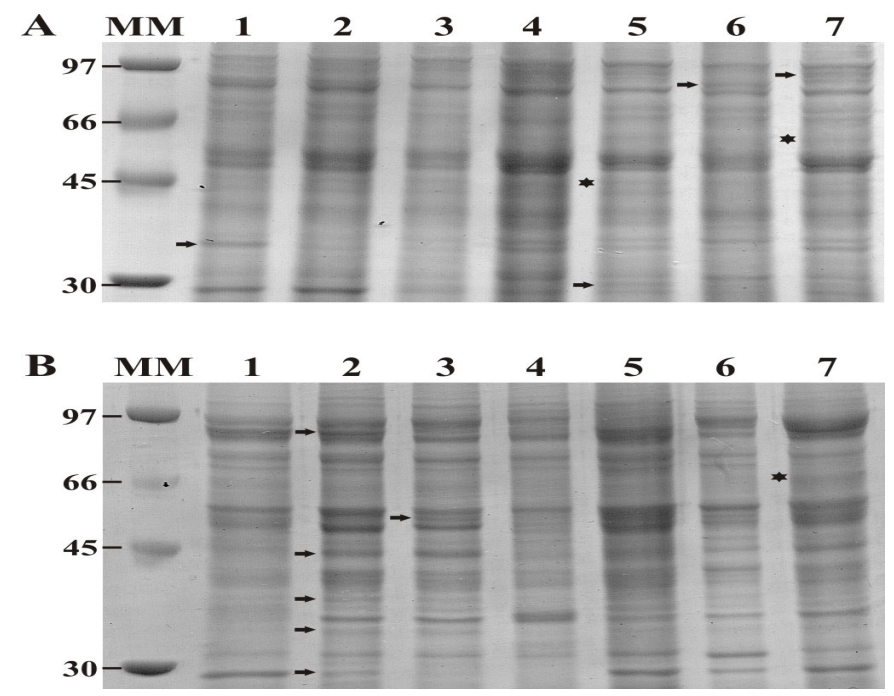

Figure 1. Separation of total protein extract of tomato pericarp at mature green (A) and red ripe stage (B) on SDS polyacrylamide gel $(10 \%)$. MM = Molecular weight marker $(\mathrm{kDa})$. Equal amounts $(20 \mu \mathrm{g})$ of proteins (lanes 1 to 7) from different $\mathrm{BC}_{1}$ plants were loaded in each well. Black arrows indicate some polymorphic bands. Black stars indicate polypeptides associated with phenotypic traits.

Table 4. Pericarp fruit polypeptides associated with fruit quality traits at two ripening stage [mature green (MG) and red ripe $(\mathrm{RR})]$ in $\mathrm{BC}_{1}$ generation.

\begin{tabular}{|c|c|c|c|c|c|c|c|c|}
\hline & Polypeptide & Trait & Mean P & NP & Mean A & NA & $\mathrm{R}^{2}$ & P value \\
\hline \multirow[t]{5}{*}{ MG } & $54 \mathrm{kDa}$ & Firmness & $51.90 \pm 1.61^{b}$ & 24 & $46.52 \pm 1.93^{\mathrm{a}}$ & 17 & 0.08 & 0.0380 \\
\hline & & $\mathrm{pH}$ & $4.64 \pm 0.04^{\mathrm{a}}$ & 24 & $4.80 \pm 0.05^{b}$ & 17 & 0.11 & 0.0220 \\
\hline & $45 \mathrm{kDa}$ & Height $(\mathrm{cm})$ & $3.11 \pm 0.07^{\mathrm{b}}$ & 22 & $2.88 \pm 0.08^{\mathrm{a}}$ & 19 & 0.07 & 0.0491 \\
\hline & & Shape & $0.88 \pm 0.01^{\mathrm{b}}$ & 22 & $0.84 \pm 0.02^{\mathrm{a}}$ & 19 & 0.08 & 0.0407 \\
\hline & & SL (days) & $15.59 \pm 1.04^{b}$ & 22 & $12.37 \pm 0.87^{\mathrm{a}}$ & 19 & 0.10 & 0.0232 \\
\hline RR & $66 \mathrm{kDa}$ & $\mathrm{pH}$ & $4.62 \pm 0.05^{\mathrm{a}}$ & 17 & $4.76 \pm 0.04^{b}$ & 27 & 0.12 & 0.0286 \\
\hline
\end{tabular}

Mean $\mathrm{P}=$ mean value for individuals with presence of the polypeptide, NP: number of individuals with presence of the polypeptide, mean $\mathrm{A}=$ mean value for individuals with absence of the amplification polypeptide, $\mathrm{NA}=$ number of individuals with absence of the polypeptide, $\mathrm{R}^{2}=$ fraction of phenotypic variance explained by the $\mathrm{QTL}$. $\mathrm{SL}=$ fruit shelf life. Different letters indicate significant differences at $5 \%$. 
These results indicated that genetic variation could be detected through these polypeptides when these two fruit ripening stages are considered. Despite that few studies using fruit pericarp polypeptide profiles as molecular markers have been carried out, these results show that this technique could be appropriate for studying segregating generations for fruit quality QTLs. Further experiments are needed to validate the QTLs detected here. However, these results indicate that both the cultivated and wild genotype have QTLs with desired effect on phenotype.

With respect to the DNA markers employed here, fifty-two amplification fragments were detected in parental genotypes among all SRAP primer combinations. Thirteen bands on average per primer combination were found. Similar average values per primer combination were found by Ruiz et al. (2005). Six fragments (11.5\%) had Mendelian inheritance and two of those were associated with phenotypic traits (Table 5). Mendelian segregation fragments allow evaluating the effect of chromosomal fragments from wild donor parent introgressed into the cultivated germplasm. Table 5 shows the SRAP bands associated with darkness, firmness, titratable acidity, and fruit soluble solids content. Some amplification fragments were associated with more than one trait (Table 5). Since SRAP markers preferentially amplify expressed sequences ( $\mathrm{Li}$ and Quiros, 2001), it is possible that these fragments have chromosomal sequences expressed in LA722 but not in CAI.

Table 5. Amplified fragments from four primer combinations associated with fruit traits in $\mathrm{BC}_{1}$ generation.

\begin{tabular}{|c|c|c|c|c|c|c|c|c|}
\hline Band & Combination & Trait & Mean P & NP & Mean A & NA & $\mathrm{R}^{2}$ & P value \\
\hline r9 397 & 3 & $\mathrm{~L}$ & $41.80 \pm 0.46^{b}$ & 22 & $40.5 \pm 0.29^{\mathrm{a}}$ & 28 & 0.10 & 0.0043 \\
\hline r9 397 & 3 & Firmness & $52.46 \pm 1.74^{b}$ & 22 & $47.90 \pm 1.46^{\mathrm{a}}$ & 28 & 0.08 & 0.0158 \\
\hline r9 397 & 3 & TA $(\mathrm{g})$ & $0.33 \pm 0.02^{\mathrm{b}}$ & 22 & $0.28 \pm 0.01^{\mathrm{a}}$ & 28 & 0.07 & 0.0159 \\
\hline r18 134 & 4 & SS ( ${ }^{\circ}$ Brix) & $6.58 \pm 0.23^{\mathrm{b}}$ & 19 & $6.06 \pm 0.13^{\mathrm{a}}$ & 33 & 0.07 & 0.0130 \\
\hline
\end{tabular}

Mean $\mathrm{P}=$ mean value for individuals with presence of the amplification fragment, $\mathrm{NP}=$ number of individuals with presence of the amplification fragment, mean $\mathrm{A}=$ mean value for individuals with absence of the amplification fragment, $\mathrm{NA}=$ number of individuals with absence of the amplification fragment, $\mathrm{R}^{2}=$ fraction of phenotypic variance explained by the QTL. $\mathrm{L}=$ darkness, TA $=$ titratable acidity, $\mathrm{SS}=$ soluble solids content. Different letters indicate significant differences at $5 \%$.

The polymorphism in the genome sequence between the wild and the cultivated tomato are not the only genetic resources required for tomato improvement. It is necessary to develop and integrate genomic, transcriptomic, and proteomics data to better understand the biology underlying fruit quality in tomato. Recent work on uniform ripening locus $(\mathrm{u})$ exemplifies this point (Powell et al., 2012). A null allele at the $u$ locus has been under positive selection by commercial breeders because it is associated with a harvest of evenly ripened fruit. However, it encodes a Golden 2-like transcription factor (SlGLK2) that is expressed in green fruit and (when functional) enhances photosynthesis, which ultimately contributes to sugar and lycopene content in the ripe pericarp. Therefore, the study of the polymorphism at the genome sequence level could be as important as the polymorphism at the transcription and protein levels when the aim of the breeder is to improve tomato fruit quality. According to Michael and Alba (2012), phenotype differences between the wild and cultivated tomatoes are mainly due to changes in the expression of the genes and the function of the protein. This analysis was based on molecular markers directly related to expressed regions on the genome as the SRAP markers are. Besides, we also analyzed the polypeptide profiles that are directly related to the fruit pericarp at the polymorphism level. They are associated with changes in 
quality traits that are defined during the fruit ripening of the genotype. Finally, this study demonstrated for the first time the usefulness of polypeptide profiles of pericarp and SRAP markers in finding associations with quality fruit traits in a tomato backcross generation.

\section{ACKNOWLEDGMENTS}

Research supported by Agencia Nacional de Promoción Científica y Tecnológica. We thank the Tomato Genetic Resources Center, University of California, Davis, CA for kindly providing seeds of the accession LA722 of S. pimpinellifolium and Estación Experimental Agropecuaria La Consulta - Instituto Nacional de Tecnología Agropecuaria, Mendoza, Argentina for kindly proving seeds of Caimanta cultivar.

\section{REFERENCES}

Castro HA, Galvez MJ, González SR and Villamil CB (2006). Protein composition of Cucurbita maxima and C. moschata seeds. Biol. Plantarum 50: 251-256.

Cravero VP, Martín EA and Cointry E (2007). Genetic diversity in Cynara cardunculus determined by SRAP markers. $J$. Am. Soc. Hort. Sci. 132: 208-212.

Del Duca S, Creus JA, Bregoli AM, Serafini-Fracassini D, et al. (2000). Tuber vegetative stages and cell cycle in Helianthus tuberosus: protein pattern and their modifications by spermidine. J. Plant Physiol. 156: 17-25.

Di Renzo JA, Casanoves F, Balzarini MG and Gonzalez L (2001). Infostat, Versión 2001, Grupo Infostat, FC. Universidad Nacional de Córdoba.

Ferriol M, Picó B and Nuez F (2003). Genetic diversity of a germplasm collection of Cucurbita pepo using SRAP and AFLP markers. Theor. Appl. Genet. 107: 271-282.

Ferriol M, Picó B, Fernández de Córdova P and Nuez F (2004). Molecular diversity of a germplasm collection of squash (Cucurbita moschata) determined by SRAP and AFLP markers. Crop Sci. 44: 653-664.

Gallo M, Rodríguez GR, Pratta GR, Zorzoli R, et al. (2010). Proteómica de la madurez del tomate: identificación de dos estados de madurez del fruto por perfiles proteicos totales del pericarpio en RILs de tomate. Rev. Fac. Cienc. Agrar. UNCuyo 42: 119-133.

Garg N, Cheema DS and Dhatt AS (2008). Genetics of yield, quality and shelf life characteristics in tomato under normal and late planting conditions. Euphytica 159: 275-288.

Giovannoni JJ (2004). Genetic regulation of fruit development and ripening. Plant Cell 16 Suppl: S170-S180.

Labate JA, Sheffer SM, Balch T and Robertson LD (2011). Diversity and population structure in a geographic sample of tomato (Solanum lycopersicum L.) accessions. Crop Sci. 51: 1068-1079.

Li G and Quiros CF (2001). Sequence-related amplified polymorphism (SRAP), a new marker system based on a simple PCR reaction: its application to mapping and gene tagging in Brassica. Theor. Appl. Genet. 103: 455-461.

Michael TP and Alba R (2012). The tomato genome flashed out. Nat. Biotechnol. 30(8): 765-767.

Miller JC and Tanksley SD (1990). RFLP analysis of phylogenetic relationships and genetic variation in the genus Lycopersicon. Theor. Appl. Genet. 80: 437-448.

Pereira da Costa JH, Rodriguez GR, Pratta GR and Zorzoli R (2009). Influencia de genes exóticos sobre la vida en estantería y el peso del fruto de tomate. Agriscientia 16: 7-13.

Powell AL, Nguyen CV, Hill T, Cheng KL, et al. (2012). Uniform ripening encodes a Golden 2-like transcription factor regulating tomato fruit chloroplast development. Science 336: 1711-1715.

Rick CM (1973). Potential Genetic Resources in Tomato Species: Clones From Observations in Native Habitats. In: Genes, Enzymes and Populations (Snb Plenum, ed.). New York, 255-269.

Rick CM (1988). Tomato-like nightshades: affinities, autoecology and breeders' opportunities. Econ. Bot. 42: 145-154.

Rodríguez GR, Pratta GR, Zorzoli R and Picardi LA (2006). Evaluación de caracteres de planta y fruto en líneas recombinantes autofecundadas de tomate obtenidas por cruzamiento entre Lycopersicon esculentum y $L$. pimpinellifolium. Cien. Inv. Agr. 33: 133-141.

Rodríguez GR, Sequin L, Pratta GR and Zorzoli R (2008). Protein profiling in F1 and F2 generations of two tomato genotypes differing in ripening time. Biol. Plantarum 52: 548-552.

Rodríguez GR, Pratta GR, Liberatti DR and Zorzoli R (2010). Inheritance of shelf life and other quality traits of tomato 
fruit estimated from F1's, F2's and backcross generations derived from standard cultivar, nor homozygote and wild cherry tomato. Euphytica 176: 137-147.

Rodríguez GR, Pereira da Costa JH, Tomat D and Pratta GR (2011). Pericarp total protein profiles as molecular markers of tomato fruit quality traits in two segregating populations. Sci. Hortic. -Amsterdam 130: 60-66.

Ruiz JJ, Gárcía-Mártinez S, Picó B and Gao M (2005). Genetic variability and relationship of closely related Spanish traditional cultivars of tomato as detected by SRAP and SSR markers. J. Am. Soc. Hort. Sci. 130: 88-94.

Shapiro SS and Wilk MB (1965). An analysis of variance test for normality (complete samples). Biometrika 52: 591-611.

Snedecor G (1964). Métodos Estadísticos. 5th Edn. Compañía Editorial.

Tanksley SD (1993). Mapping polygenes. Annu. Rev. Genet. 27: 205-233.

Tomato Genome Consortium (2012). The tomato genome sequence provides insights into fleshy fruit evolution. Nature 485: 635-641.

Zorzoli R, Pratta GR and Picardi LA (2000). Variabilidad genética para la vida poscosecha y el peso de los frutos en tomate para familias F3 de un híbrido interespecífico. Pesq. Agropec. Bras. 35: 2423-2427. 